\title{
Hobbes and the Congo: Frames, Local Violence, and International Intervention
}

\author{
Séverine Autesserre
}

\begin{abstract}
Why do international peacebuilders fail to address the local causes of peace process failures? The existing explanations of peacebuilding failures, which focus on constraints and vested interests, do not explain the international neglect of local conflict. In this article, I show how discursive frames shape international intervention and preclude international action on local violence. Drawing on more than 330 interviews, multi-sited ethnography, and document analysis, I develop a case study of the Democratic Republic of Congo's transition from war to peace and democracy (2003-2006). I demonstrate that local agendas played a decisive role in sustaining local, national, and regional violence. However, a postconflict peacebuilding frame shaped the international understanding of violence and intervention in such a way that local conflict resolution appeared irrelevant and illegitimate. This frame included four key elements: international actors labeled the Congo a "postconflict" situation; they believed that violence there was innate and therefore acceptable even in peacetime; they conceptualized international intervention as exclusively concerned with the national and international realms; and they saw holding elections, as opposed to local conflict resolution, as a workable, appropriate, and effective tool for state- and peacebuilding. This frame authorized and justified specific practices and policies while precluding others, notably local conflict resolution, ultimately dooming the peacebuilding efforts. In conclusion, I contend that analyzing discursive frames is a fruitful approach to the puzzle of international peacebuilding failures beyond the Congo.
\end{abstract}

My most heartfelt thanks go to my interviewees. I also thank Michael Barnett, Alexander Cooley, Kevin Dunn, Daniel Greenberg, Robert Jervis, René Lemarchand, Kimberly Marten, Philippe Rosen, Ingrid Samset, Jack Snyder, Stephen John Stedman, Timothy Mitchell, Jean-Claude Willame, Elisabeth Jean Wood, the editors and reviewers for International Organization, and the participants of the various conferences and workshops at which I presented this article, for their very helpful comments on its various drafts. Finally, I am greatly indebted to the teams of Action Against Hunger for their help during my fieldwork. This research was financed by a Peace Scholar award from the United States Institute of Peace, two Mellon fellowships from the Inter-University Consortium on Security and Humanitarian Aid, a McCracken fellowship from New York University, a postdoctoral fellowship from Yale University, and a faculty fellowship from Barnard College, Columbia University. The views expressed in this article are mine alone and do not necessarily reflect the views of my donors or my interviewees. 
Academics and policymakers often emphasize the pressing need to explain the failures of international interventions in civil wars. Most recent militarized conflicts have been internal wars. While most of these civil wars ended in negotiated peace agreements, more than half of them lapsed back into war within a few years. The study of these failures has yielded two main findings. First, most negotiated peace agreements fail during the implementation phase. Second, significant thirdparty involvement is critical for peace implementation to be successful, but 70 percent of peace processes benefiting from significant international mediation still fail to build a durable peace. How can one explain these failures? ${ }^{1}$

Recent work in comparative politics and international relations suggests that the continuation of violence during peace agreement implementation is at least partly driven by local agendas - at the level of the individual, the family, the clan, the municipality, the community, the district, or the ethnic group. ${ }^{2}$ However, international actors often fail to address the local causes of violence. Why then do peacebuilders neglect to address the local causes of peace process failures, particularly when they threaten the macro-level settlements? ${ }^{3}$

This article seeks to improve understanding of international interventions. Because no peace implementation analysis studies the importance of local preconditions for peace settlements, how international actors approach the micro-level dynamics of violence is unknown. ${ }^{4}$ Furthermore, there is little theoretical understanding of why, among the many possible peacebuilding strategies, international actors prioritize certain approaches over others. Almost all the existing theoretical studies of peacebuilding implementation focus on the influence that vested interests and economic, political, legal, security, and contextual constraints have on the nature, level, and effectiveness of international involvement. ${ }^{5}$ They do not explain whether, how, or why these constraints and interests lead international actors to use specific peacebuilding strategies (for example, elections organization) at the expense of others (such as local conflict resolution, security-sector reform, or transitional justice).

In this article, I explain the international neglect of local violence by using the concept of frames: collective, intersubjective understandings that "people 'draw

1. On internal wars, see Fearon and Laitin 2003; and Doyle and Sambanis 2006. On peace agreements, see Woodward 2006; on their frequency, see Fortna 2004; and on their failure, see Licklider 1995; Weinstein 2005; and Walter 2002. On third-party involvement, see Walter 2002; and Stedman, Rothchild, and Cousens 2002; and on its failures, see Doyle and Sambanis 2006.

2. See Adam 2005; Autesserre 2006b; and Krämer 2006.

3. In this article, "international peacebuilders" refers to all international actors (persons, countries, or organizations) who aim, at least in part, to build peace or to support the Congo in its peacebuilding efforts. Such actors can be diplomats (in embassies as well in the headquarters of their respective foreign affairs ministries), other government officials (such as defense officers), staff of international organizations, and staff of nongovernmental organizations.

4. Power 2002; Stedman 1997; and Wood 2000 briefly mention the influence of specific local factors on peace processes, but none of them analyze the local issues in a systematic way.

5. On constraints, see Stedman, Rothchild, and Cousens 2002 (especially chap. 2); Doyle and Sambanis 2006; and Zartman 1989. On vested interests, see Ottaway 2002; Stedman 1997; Stedman, Rothchild, and Cousens 2002; and Touval and Zartman 1985. 
on' to construct roles and interpret objects." 6 I identify a "postconflict peacebuilding" frame shared by international actors belonging to many different organizations, such as diplomacies, international organizations, and nongovernmental agencies. Rich ethnographic data demonstrates how this frame shapes the peacebuilders' understanding of violence, peace, and international intervention-an understanding that makes local conflict resolution appear to be an inappropriate and illegitimate action. I detail how this frame creates constraints and interests that international actors interpret as obstacles to their involvement at the local level and also explains why international actors persist in using their existing peacebuilding strategy when its failure becomes evident.

Using a case study of the recent transition from war to peace and democracy in the Democratic Republic of Congo, which was the stage of the deadliest conflict since World War II and host to the largest and most expensive peacekeeping mission in the world, I identify four central elements of the postconflict peacebuilding frame: the labeling of the Congo as a "postconflict" situation; the belief that violence is innate in the Congo; the conceptualization of international intervention as exclusively concerned with the national and international realms; and the vision of elections, as opposed to local conflict resolution, as a workable, appropriate, and effective tool for state- and peacebuilding. All four elements were essential parts of the frame and they all had a significant influence on international action: the first two shaped the international understanding of violence in the Congo; the last two shaped the international actors' understanding of their role in a postconflict situation. Each of these elements precluded international action on local violence. They guided when international peacebuilders did and did not act to stop ongoing conflicts, ultimately dooming the international efforts.

Between 2001 and 2007, I conducted a multi-sited ethnography in various parts of the Congo. There, and in France, Belgium, and the United States, I interviewed more than 330 people, from international peacebuilders and victims of violence to Congolese political, military, diplomatic, and civil society actors. I also analyzed multiple documents, including policy reports, agency memos, confidential papers, and news articles.

Part of what shaped the international understanding of the Congolese transition is that international actors categorized the Congo as a "postconflict" environment, which carried major assumptions about appropriate strategies for intervention. They also saw the continuation of violence in the eastern provinces as a normal feature of life in the Congo even in peacetime, not as evidence that war continued. Only when shocking events took place did international actors temporarily recategorize the Congo as a war situation and intervene to reduce local violence. However, even in these cases, two other elements of the postconflict peacebuilding frame shaped the international actors' understanding of their role: diplomats and UN staff perceived the national and international realms as their "natural" levels of action, 
and viewed elections as a workable, appropriate, and effective tool for state- and peacebuilding. They therefore never considered intervening at the local level. After this presentation of the peacebuilding frame, I examine alternative explanations for the international neglect of local conflict to show that they are either insufficient or inconsistent with the data.

\section{Understanding International Intervention}

Although many concepts such as culture, representation, dispositif, or schema could be used to study the influence of discourse on peacebuilding strategies, the concept of frames has an important advantage: it focuses the analysis on how people organize knowledge and interpret it. Frames can account for what shapes the international understanding of the causes of violence and of the interveners' role, and how this understanding makes certain actions possible while precluding others.

An extensive literature on frames has developed since Goffman first coined the concept. ${ }^{7}$ In political science for example, researchers have used a frame analysis to investigate many different forms of international action, such as economic development, refugee policy, nuclear strategies, humanitarian intervention, UN peacekeeping, and human rights advocacy movements. ${ }^{8}$ This section builds on their work to present the four characteristics of frames that are most useful for understanding peacebuilding failures: what frames are, where they come from, how they operate, and how they relate to strategic explanations.

Frames are social objects - they are not only inside individual heads (as psychological approaches would argue $)^{9}$ but are also embedded in social routines, practices, discourses, technologies, and institutions. They can consist of ideologies, "assumptions and definitions taken as given" (for example, Congolese are inherently violent), and paradigms (for example, the liberal peace)—which include standard operating procedures (for example, elections organization) and "shared definition of the environment" (for example, the Congo is a postconflict situation). ${ }^{10}$

Two debates on the sources of frames are particularly relevant here. First, frames can either pre-exist action or they can emerge from practice. ${ }^{11}$ During the Congolese transition, the postconflict peacebuilding frame was mostly an instance of the former except for one of its central elements: the postconflict label. The understanding of the Congo as a "postconflict" environment was indeed constituted following the process documented by Porac and colleagues: "subjective interpretations of externally situated information [became] themselves objectified via behavior... This con-

7. Goffman 1974.

8. See Barnett and Finnemore 2004; Eden 2004; Keck and Sikkink 1998; and Shaw 2007.

9. For a political science application, see Jervis 2006.

10. Weick 1995, chap. 5 .

11. See ibid., for an overview of the sociological literature on the topic. I use the Keck and Sikkink 1998, 35, definition of practice as "the act of doing something repeatedly." 
tinual objective-subjective-objective transformation [made] it possible eventually to generate interpretations that [were] shared by several people." ${ }^{12}$ In 2002, Western diplomats interpreted the signing of a general peace agreement as the end of the conflict in the Congo. They enacted this interpretation via concrete activities (notably through funding and diplomatic negotiations); nongovernmental organizations (NGOs) and Congolese actors interpreted these activities as cues that the Congo had indeed entered a postconflict stage and adapted their strategies, and over time the label "postconflict" became the dominant understanding of the environment.

Second, the few authors working on discourse's influence on peacekeeping strategies disagree on whether frames should be located in the culture internal to international organizations or external to them. For example, Barnett and Finnemore root frames in the internal culture of international bureaucracies. ${ }^{13}$ I similarly identify a powerful organizational element in the postconflict peacebuilding frame: the UN and embassy staffs' understanding of their role as exclusively concerned with national and regional peace settlements. ${ }^{14}$ However, Barnett and Finnemore's organizational approach would expect different organizations to behave differently. It cannot explain why different actors with distinct identities, internal cultures, and interests show puzzling behavioral similarities. ${ }^{15}$ Such similarities suggest that the source of the frame elements have to be located beyond the organization, both at the level of the field, defined as an increasingly structured set of organizations that "in the aggregate constitute a recognized area of institutional life," and at the level of the world polity. ${ }^{16}$ Cultural and normative understandings shared by the actors of the peacebuilding field (such as the "postconflict" label and the focus on elections) and of the world polity (such as the understanding of violence as normal for the Congo) explain why organizations as different as the UN, the United States, South Africa, and many NGOs could adopt the same understanding of the situation and similar intervention strategies. Frame elements coming from the culture external to these organizations were translated into specific routines, rules, and procedures in different institutional spaces.

Table 1 summarizes the sources of the frame's four elements: whether these elements were-or became-part of a culture that was located inside or outside of international organizations; in the latter case whether the culture was truly global (at the level of the world polity) or restricted to the peacebuilding field; and in all cases whether these elements pre-existed the international intervention in the Congo or emerged from practice.

12. Porac, Thomas, and Baden-Fuller 1989, 398-99, cited in Weick 1995, 79. See also Berger and Luckmann 1967. The following sentences, just as the process they describe, paraphrase and build on Weick 1995, 79-80.

13. See Barnett 2002; and Barnett and Finnemore 2004.

14. In this article, regional means at the level of the African Great Lakes region (Rwanda, Uganda, Burundi, Congo).

15. This criticism builds on Finnemore 1996.

16. The definition of field comes from DiMaggio and Powell 1983, 148; the idea of locating frames in the world polity from Paris 2003; and Finnemore 1996. 
TABLE 1. Sources of the frame's four elements

\begin{tabular}{|c|c|c|}
\hline & $\begin{array}{l}\text { Emerged from } \\
\text { practice }\end{array}$ & Pre-existed action \\
\hline \multicolumn{3}{|c|}{$\begin{array}{l}\text { Cultures external to the international } \\
\text { organizations }\end{array}$} \\
\hline World polity & & Violence innate to Congo \\
\hline Peace-building field & Postconflict label & Focus on elections \\
\hline $\begin{array}{l}\text { International organizations } \\
\text { internal cultures }\end{array}$ & & $\begin{array}{l}\text { Focus on national } \\
\text { and regional realms }\end{array}$ \\
\hline
\end{tabular}

Scholars studying the influence of discourse on international interventions often leave the study of how frames operate on the ground for further research. ${ }^{17}$ Frames shape how people understand the world and, based on this understanding, what they perceive to be appropriate action.

One of the most important insights of the extensive literature on frames is that problems are not given, they have to be constructed ${ }^{18}$ and frames shape people's views on what counts as a problem and what does not. For example, the understanding of violence as normal for a peaceful Congo prevented international actors from constructing continued conflict in the eastern provinces as a problem. ${ }^{19}$ Frames also affect which events will be noticed and which will not, as well as how they will be interpreted..$^{20}$ For instance, because diplomats believe that they should focus on the macro level, they found (or privileged) information confirming that the sources of violence lay at those macro levels.

One of the ways in which frames organize knowledge is through categories. Frames reify and perpetuate arbitrary and often dichotomous categories such as man/woman, war/peace, or barbarian/civilized. These distinctions shape one's understanding of objects or processes and how one acts toward or within them. For example, labeling the Congo a "postconflict" situation instead of a "war" made a specific set of policies and procedures (such as elections organization) seem natural and appropriate while it made another set of strategies (such as work on local conflicts) seem inappropriate and illegitimate.

17. See, for example, Paris 2003.

18. See Weick 1995; Barnett and Finnemore 2004; and Eden 2004.

19. Many philosophers, psychologists, historians, anthropologists, feminist theorists, and political scientists have studied the process by which violence on specific groups of people comes to be considered as normal. However, these authors have focused either on the perpetrator (Goldhagen 1997; Kelman and Hamilton 1989; and Wilmer 2002) or on the victim (Foucault 1975; and most of the post-Foucauldian, feminist, and anticolonialist literatures). Little has been written on the third actor of most abuse and trauma situations: the "silent witness" (Herman 1992). This article explores the process by which witnesses of massive human rights violations come to perceive this violence as normal.

20. See Weick 1995; and Barnett and Finnemore 2004, 32-33. 
Thus, frames do not cause action; they make it possible by establishing "the conditions of possibility for objects or events." ${ }^{21}$ For example, frames constitute specific identities (such as "a diplomat" as understood in the early twenty-first century Europe), interests (such as UN organizational interests), and assumptions that are taken as truth (such as "the Congo is inherently violent"). ${ }^{22}$ These identities, interests, and assumptions authorize, enable, and justify specific practices and policies while precluding others (for example: diplomats should work on international dialogues and not on local conflict). These actions in turn reproduce and reinforce both the dominant practices and the meanings upon which they are predicated (the frames). Over time, the frames and the practices they authorize come to be taken as "natural," "granted," and the only conceivable ones.

While looking at frames helps explain change, it also explains resistance to change. Two mechanisms explain such resistance. First, people usually tend to interpret new information as a confirmation of existing belief. ${ }^{23}$ Second, largescale bureaucracies (such as the United Nations, which was the most powerful international actor during the Congolese transition) are notoriously resistant to change because they rely on routines and stability to function and because change usually "threatens entrenched organizational culture and interests." ${ }^{24}$ Of course, organizations do change: several recent studies have shown that "probably the most likely impetus to reinterpretation of the environment, or organizational mission within it," is when key actors interpret "external change or shock" as threatening organizational survival..$^{25}$

Diplomats and international organization managers constantly reproduced the postconflict peacebuilding frame while inhabitants of the eastern Congo, as well as some NGOs, contested it. Their efforts succeeded only when shocking events, such as unexpected, genocidal, or particularly horrific violence took place. In these cases, UN officials reinterpreted the continued violence: it was no longer considered a "normal" feature of a peaceful Congo; it was evidence that the war was continuing. As such, it threatened the survival of the UN peacekeeping mission, and UN officials had to address it immediately. However, this recategorization of parts of the Congo as war environments affected only one element of the peacebuilding frame (the label postconflict and the strategies it authorized); it did not influence the others. Diplomats and UN staff members usually interpreted shocking violence as a confirmation of their beliefs that Congolese were violent by nature

21. This sentence builds on Finnemore 1996, fn. 15. As should be clear by now, the aim of this article is therefore not to develop a "linear, causal analysis between independent and dependent variables" in order to provide law-like statements (Klotz and Lynch 2007, 36; see also Finnemore 1996). It is rather to document a dispersed process, where social objects have multiple sources, and where ideas, actions, and environmental constraints mutually constitute each other.

22. This paragraph builds on Klotz and Lynch 2007, 38 .

23. See Weick 1995, chaps. 4 and 6, for a review of the sociological and psychological literature on this topic.

24. See Barnett and Finnemore 2004, 2; Eden 2004; and Weaver 2008.

25. Eden 2004, 57. 
and that violence was a consequence of macro-level conflict. As a result, they still conceived of their role as focused on the national and regional realms, and especially on elections. They never considered that micro-level conflict could cause violence or that working at the local level could be an appropriate strategy. Thus, when they intervened to stop shocking violence, they mostly tried to bring violence back to a "normal" (that is, less horrific and non-genocidal) level, at which point the targeted area could be recategorized as a postconflict environment.

One last theoretical point still needs clarification: the respective roles of structure and agency. My work here places much less emphasis on strategic intent than do many other frame analyses. ${ }^{26}$ Strategic intent can exist (for example, the Belgian state constructed the image of an inherently violent Congo in order to facilitate its colonial enterprise) but it can also be absent (for example, nobody strategically labeled the Congo as a "postconflict" environment in order to preclude international interactions with domestic actors). Of course, this is not to say that agency plays no role at all. Agents and structures are mutually constituted-in fact, agency helps explain frame constitution (through practice), contestation, and change.

\section{Local Violence and International Intervention in the Congo}

Local agendas have been a source of violent conflict throughout modern Congolese history. ${ }^{27}$ Micro-level rivalries over land, resources, and traditional or administrative power produced a series of cleavages both at the local and at the national level. Most of the conflicts involved only a few villages, communities, or provincial leaders, but some-most notably the conflict between the Rwandophone minority and the "indigenous" communities of the Kivus-were reinforced by topdown manipulation by national and provincial actors. ${ }^{28}$ All these local tensions caused serious violence during the decades that followed Congolese independence in 1960. Combined with the retreat of the Congolese state in the 1980s, Mobutu Sese Seko's ruling strategy-which enhanced local antagonisms-coupled with the arrival of thousands of Rwandan Hutus after the 1994 genocide precipitated two successive large-scale conflicts in the late 1990s.

During the second conflict, which started in 1998, Rwanda, Uganda, and Burundi organized and armed various rebel groups, while Zimbabwe, Angola, Namibia, and (to a lesser extent) Chad and Sudan supported President Laurent Désiré Kabila.

26. See, for example, Benford and Snow 2000; or Keck and Sikkink 1998.

27. See Autesserre 2006a; Mamdani 2001; Van Acker and Vlassenroot 2000; and Willame 1997. See Kalyvas 2006 for the seminal analysis of the role of local conflict in civil war violence.

28. Rwandophone, literally "Kinyarwanda-speaking people," is used in the Congolese context to refer to the Congolese of Rwandan ancestry (Hutus and Tutsis). 
Over time, up to fourteen foreign armies became active on Congolese territory, as well as three main rebel groups and countless fragmented militias.

From 1999 onward, most violence took place behind the official frontlines. Fighting remained concentrated in the east (the provinces of North Kivu, South Kivu, north Katanga, and the district of Ituri-see Figure 1) while the northern and western parts of the country enjoyed relative stability. Civilians were the primary victims: more than 3.3 million died between 1996 and 2003, mostly in the eastern Congo. ${ }^{29}$

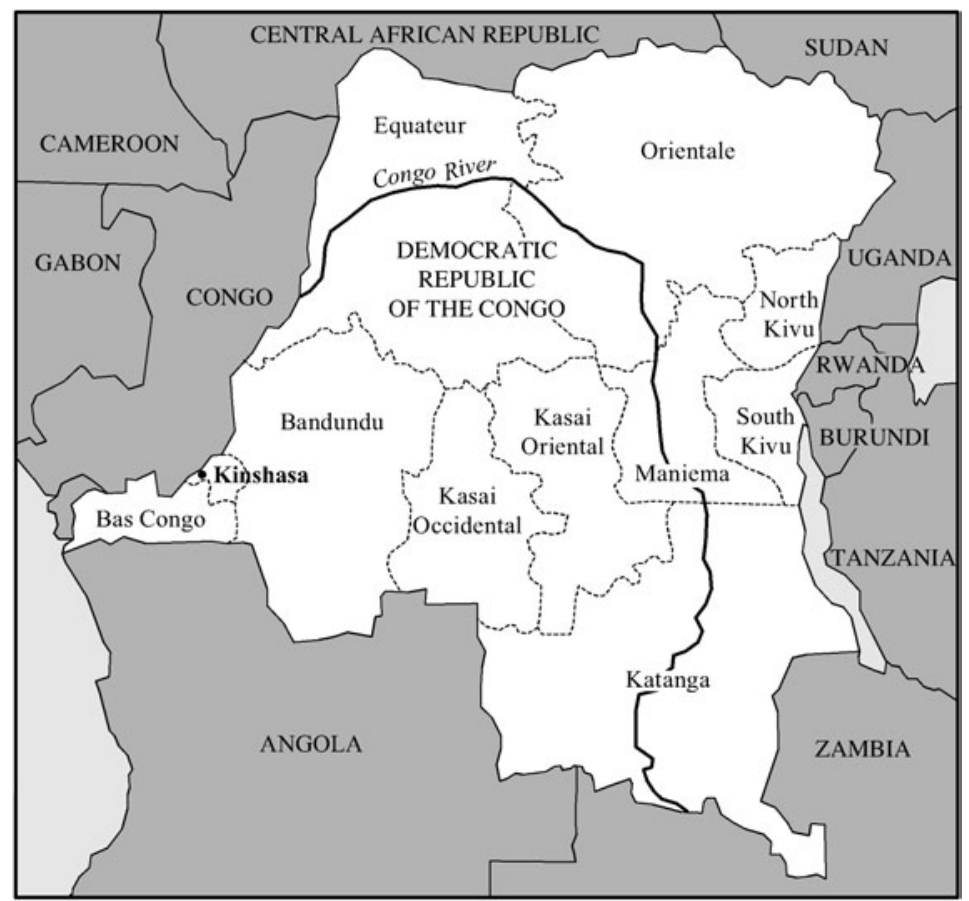

FIGURE 1. Map of the Congo

Within days after the commencement of the first war, African and Western diplomats started supervising the Congolese peace processes. The UN deployed a peacekeeping mission, the Mission de l'Organisation des Nations Unies au Congo, or MONUC, which progressively became the largest and most expensive UN mission in the world. Although the peace agreements were ineffective for several years, 
the warring parties reached a "peace settlement" in June 2003 which, according to many international and Congolese interviewees, was imposed on them by the international community. During the three years officially dedicated to the transition from war to peace and democracy (2003-2006), diplomats retained a tremendous influence on Congolese affairs, to the point that numerous top Congolese political leaders, international actors, and journalists equated the situation in the Congo to that of a "protectorate." 30

From June 2003 onward, due to this heavy international pressure, a relative settlement seemed to have been reached at the international and national levels. The foreign troops that withdrew from the Congo in 2002 and 2003 officially remained out of Congolese territory. The assistance to, and manipulation of, Congolese fighters by regional actors dramatically decreased, even though Rwanda and Uganda continued to give some limited and unofficial support to selected Congolese armed groups. ${ }^{31}$ Normal diplomatic ties, such as the exchange of ambassadors, resumed between former enemies. Important developments also took place at the national level, such as the official reunification of the country, the formation of a unified government, the preparation for democratic elections, and a progressive integration of the different armed groups into a single national army. However, more than 1,000 civilians continued to die every day. ${ }^{32}$ In late 2007, large-scale fighting destabilized the entire province of North Kivu. There, as in most of the surrounding provinces, local conflict persisted in fueling massive violence. ${ }^{33}$

North Kivu was marred by the combination of tensions among its eight ethnic communities and among the five networks of armed groups present in the province. Most sources explained the violence as caused by the master ethnic cleavage (Rwandophones versus "native" communities), neatly superimposed and running along the same dividing line as the national and regional political cleavage (President Kabila versus the former rebel group Rassemblement Congolais pour la Démocratie-Goma, or RCD-G, supported by Rwanda). This reading of the conflict overlooked the key role of local tensions: Kabila's allies in North Kivu fought the RCD-G for provincial and local reasons rather than their convictions about the national or regional conflict.

Since colonization, North Kivu progressively experienced a strong polarization between its two most populous ethnic groups, the Rwandophones and the Nandes,

30. Author interviews, 2003-2007.

31. Author interviews with diplomats and UN staff members, 2001-2007; and U.S. Department of State 2007.

32. International Rescue Committee 2005.

33. The following paragraphs briefly summarize my research findings on the dynamics of violence in the eastern Congo. See Autesserre 2006b and 2007 for a thorough analysis and for micro-level case studies. The analysis of Congolese local politics is based on International Crisis Group 2004 and 2006b; Van Acker and Vlassenroot 2000; Vlassenroot and Raeymaekers 2004; Vlassenroot and Romkema 2002; and Willame 1997, as well as the author field observations in the Kivus, North Katanga, and Ituri, 2001-2007; interviews with inhabitants and international actors deployed in these different provinces, and newspaper articles. 
over the control of the province. At the district and village levels, "indigenous" (meaning, non-Rwandophone) communities asserted that they were the only communities with a rightful claim on representation. This led to major tensions regarding the designation of traditional chiefs or district administrators. In addition, Rwandophones owned the majority of the land as a result of transactions they had made under President Mobutu, but the indigenous communities claimed that Mobutu should not have been allowed to sell the land because it belonged to traditional authorities. These political and economic antagonisms were carried onto the military stage both during and after the war. They caused numerous skirmishes between 2004 and 2008 and they erupted in large-scale confrontations in December 2004, October 2007, and August 2008. In North Kivu, national and regional cleavages were therefore as influential as local agendas in generating violence.

In South Kivu, by contrast, the master cleavages carried little weight. In May 2004, armed groups allied with President Kabila defeated RCD-G troops stationed there. RCD-G authorities lost administrative control of the province and the Rwandophone population fled to surrounding areas. This marked the quasi-disappearance of the ethnic and political master cleavages from South Kivu politics. Yet South Kivu was far from pacified. Dozens of fragmented, micro-level militias called Mai Mai, sometimes allied with foreign rebel groups, continued their armed struggle because many local conflicts remained unresolved. Antagonisms revolved around the leadership of specific militias (such as between General Dunia and Colonel Nguvu); disagreement over who could control the political and economic resources won by the group; appointment to local administrative positions (such as between Mai Mai Tembo and Mai Mai Rega in Shabunda territory); opposing claims on land, mining sites, and traditional positions among villagers (such as in Walikale territory); ethnic tensions (such as Tembos versus Shis); and clan tensions (such as those among Bembe subclans).

There was no hierarchy controlling the Mai Mai, neither nationally nor, sometimes, even within one city (such as Uvira after June 2004). Moreover, each militia was divided into subgroups and subfactions to such a point that many brigade commanders could not seem to control their battalion commanders.

The continued insecurity in North Katanga was also attributable mostly to local factors. National cleavages had little influence: RCD-G military and administrative authorities had either disappeared or switched sides, and there were no Rwandophones to harass. Regional cleavages were similarly noninfluential because foreign armed groups had left the province. Nevertheless, many areas remained plagued by micro-level, uncontrolled armed groups-mostly Mai Mai. These soldiers spent most of their time harassing the civilian population and fighting against the national army, or among themselves, for political, economic, and ethnic reasons similar to those of the South Kivu militias. At the territory or village level, Mai Mai groups strived to maintain power over their former areas of control in order to dominate the administrative and traditional powers, manage mineral-rich areas, control land, and divert taxes. These political and economic agendas interacted with numerous ethnic tensions: hatred of pygmies and "Kasaian" groups per- 
sisted in the whole province, while in each district many other clan, tribal, or ethnic rivalries continued to simmer. As a result, in late 2004 and 2005, there was constant fighting between the Congolese armed forces and Katangan Mai Mai, as well as major abuses against the local population, notably around Mitwaba, Kongolo, and Malemba Nkulu.

The situation was extremely similar in Ituri. Only a small portion of the numerous armed groups that formed during the war agreed to disarm when the conflict officially came to an end. The others continued to fight amongst one another over land issues: to retake control of local mining sites or of territory that traditionally belonged to their ethnic group. There was some Ugandan involvement in the district - in order to exploit Congolese resources illegally—but, according to many international and Congolese sources, most violence was driven by micro-level conflict.

In sum, during the transition, just as during the war, violence was motivated not only by the regional and national causes usually emphasized in the civil war literature but also by longstanding bottom-up agendas, whose main instigators were villagers, traditional chiefs, community chiefs, or ethnic leaders. Local manifestations of violence, although often related to national or regional struggles, were also precipitated by distinctly local problems.

Even issues usually presented as regional questions (such as the violence waged by Rwandan Hutu militias in the Congo) or national ones (such as ethnic tensions with the Congolese Rwandophones) had significant local components, which fuelled and reinforced the regional and national dimensions. Local alliances were critical to perpetuating the presence of Rwandan Hutu rebel groups on Congolese territory and the violence associated with it. The tensions with the Rwandophone minority had been caused by competing claims on land and traditional power during colonization and, a century later, Rwandophones' claims on traditional political power-and their associated claims on land-continued to fuel ethnic hatred.

Of course, local, national, and regional dimensions of violence remained interlinked. Local militias continued to ally themselves with national and regional actors, even if they did so to a much lesser extent than in the past. Local agendas provided national and regional actors with local allies, who were crucial in maintaining military control, continuing resource exploitation, and persecuting political or ethnic enemies. However, most of the massacres, human rights violations, and population displacement that took place during the transition were not coordinated on a large scale: they were perpetrated by local strongmen accountable to no one but themselves.

Thus, addressing local issues was key to ending violence and to ensuring the stability of the national and regional settlements. Because the causes of violence varied so greatly between and within each province, peacebuilders should have tailored their strategies to each specific local context. However, except for ad hoc efforts, diplomats and UN agencies' almost never got involved in local conflict resolution. 
To quell local violence, diplomats and UN staff members relied on the deterrent presence of the international peacekeeping troops. ${ }^{34}$ They left the responsibility for conducting local peacebuilding work to Congolese authorities, religious leaders, and NGOs. Except for a few, Congolese authorities and religious leaders were either unwilling or unable to conduct local peacebuilding — or they were involved in fueling violence. A handful of Congolese and international NGOs implemented local peacebuilding projects, but their numbers were too few and they faced too many challenges to be able to address all the local tensions. Why did most international actors ignore the continuation of local conflicts?

There is so far no scholarly study of international intervention during the Congolese transition. Journalists' and policy analysts' explanations for the failures of peacebuilding there mirror the two explanations found in the academic literature to explain the choice of poor peacebuilding strategies: international actors are constrained, or they are subverted by vested interests. ${ }^{35}$ In the Congo, constraints and interests certainly played a role in shaping the (lack of) international response to local conflicts. However, the existing constraints and interests could have produced many different outcomes, such as a focus on local conflict resolution at the expense of elections. Instead, they caused a neglect of local violence because of the presence of a postconflict peacebuilding frame.

\section{A 'Postconflict' Situation}

The most important element of this frame was the labeling of the Congo as a "postconflict" situation. In December 2002, regional actors signed a peace agreement in Pretoria, South Africa. Many diplomats based outside of the Congo interpreted this as the end of the Congolese war. As one of them recalled, from then on, they "started working in another framework: the implementation of the peace process, of peace, [they] were no longer in a conflict zone." 36

At first, most field-based actors contested this new categorization of the Congo as a postconflict situation. In mid-2003, for example, a Europe-based donor visited North Kivu and met with the international NGOs working there. ${ }^{37}$ He told them that they had to get outside of the wartime frame of mind and to start conducting activities across the frontline because the Congo was finally at peace. The audience found this statement ludicrous and widely challenged it: at that time, heavy fighting had just resumed in North Kivu.

Progressively, however, all actors (journalists, donors, and even humanitarian NGOs confronting violence on a daily basis) adopted the postconflict language.

34. This paragraph is based on author field observations and interviews, 2001-2007.

35. See, for example, Braeckman 2003; Nbanda Nzambo 2004; and Staibano 2005.

36. Informal communication, 2008.

37. The rest of this paragraph is based on author participant observation. 
This shared understanding of the situation was fashioned through practice. Diplomats based outside of the Congo enacted their interpretation of the Congo as a postconflict situation via concrete activities. Belgium reviewed its priorities: economic and political matters became more important than security issues. ${ }^{38}$ The United States stopped advocating for an intercommunity dialogue in the Kivus. ${ }^{39}$ High-ranking diplomats, as well as the UN's top managers, started considering local conflict as an internal matter that fell under the expertise of the transitional government. ${ }^{40}$ Donors such as the European Union started disbursing development funds. ${ }^{41}$ Because the UN mission was from then on considered a "peacekeeping" mission and not a peace-enforcement one, soldiers deployed in the Congo did not expect to fight and combat material was not always available. ${ }^{42}$ Similarly, MONUC civilian officials were sent "to make peace, not war." ${ }^{43}$ Then, in a process similar to that which Weick describes,${ }^{44}$ NGOs and Congolese people "noticed these changes" and interpreted them as cues that the Congo had entered a postconflict phase. They "acted on these new interpretations in ways that verified the original interpretation:" they initiated development and postconflict reconstruction programs. These actions "constrained the information" the different organizations got back-by reinforcing the belief that the Congo was indeed a postconflict situation - and thus "affected the next round of choices." Extensive formal and informal communication amongst international actors (during meetings, after work drinks, parties, and through e-mail exchanges) helped diffuse this interpretation. Over time, it became "objectified" and "widely internalized into" a shared understanding of the situation: the Congo was a postconflict environment.

This new categorization of the Congo ushered in a change in the material and intellectual tools that international actors used to understand the situation and act within it. These tools were different for each organization but they shared one characteristic: they were appropriate for peaceful environments and not for conflictive ones. Especially, the "postconflict" designation created an additional constraint on UN staff and diplomats. ${ }^{45}$ Because the Congo was not at war, subnational actors could not be conceptualized as "rebels" or "warring parties" anymore. Instead, the term "postconflict" drew a distinction between who could be seen as a legitimate partner and who could not and, consequently, who diplomats could meet

38. Author interview with Jozef Smets, Belgian Ministry of Foreign Affairs, Brussels, May 2005.

39. Author interviews and informal communications with U.S. governmental and nongovernmental actors, 2003-2007.

40. Author field observations; and author's informal conversations and interviews with MONUC officials and diplomats, 2004-2007.

41. Author field observations and interview with European Union (EU) officials, 2003-2007.

42. Cowan 2005; author field observations and informal conversations with MONUC officials, 20042007; and Radio France International, 2 March 2005.

43. Author informal conversation with MONUC staff member, 2004.

44. Weick 1995, 79-80.

45. This was particularly obvious in the author's 2005 interviews with two foreign diplomats and a MONUC official. 
and negotiate with (the actors participating in the transition) versus those who were now considered "illegal" (the actors continuing to wage violence and not participating in the transition). Diplomats and UN staff were not supposed to meet with the illegal actors officially; it would risk legitimizing and reinforcing them. Mediation between different combatants was now not an option because at least one of the parties was considered illegitimate.

The problem of the "renegade colonel" Laurent Nkunda illustrates the consequences of these new constraints. In the first months of 2004, when warning signs of an impending crisis were developing, Nkunda was categorized as an illegal actor with whom UN officials were forbidden to meet. ${ }^{46}$ The logic of exclusion and repression continued until it was too late: Nkunda took over the eastern city of Bukavu in May 2004 and MONUC officials were forced to deal with him. In 20062007, when it became obvious that Nkunda was building a quasi-independent state in the North Kivu province, the top UN hierarchy similarly prevented its staff from meeting with the agitator. ${ }^{47}$ The failure of this strategy became evident in late 2007, when heavy fighting resumed between Nkunda and the Congolese army.

Of course, a multiplicity of voices contested the "postconflict" categorization and the strategies and policies it enabled. The Kivus' inhabitants maintained that the conflict was still underway; they called the major fighting "wars" instead of "crises;" and they requested military intervention and protection against warlords. Human rights and humanitarian agencies wrote numerous reports documenting the continuation of violence in the eastern provinces and pleading for immediate international action. However, except in the few cases documented below, their interpretation remained marginalized because of the presence of a second element of the postconflict peacebuilding frame: the understanding of violence as a normal feature of a peaceful Congo.

\section{A 'War of All Against All'}

International actors usually pictured the Congo as an inherently turbulent country where violence was expected even in times of peace. To a UN official, violence and corporal punishments were part of Congolese life. ${ }^{48} \mathrm{~A}$ UN peacekeeper conjectured that the mounting violence in the Kivus in 2007 might have been just the "typical state of affairs" for these provinces. ${ }^{49} \mathrm{~A}$ Western diplomat sincerely argued that, after a decade of serious fighting, regarding violence toward the Congolese population as normal was just as "legitimate" as judging high levels of shooting

46. Author interviews with MONUC officials, 2004-2005.

47. Author interviews with MONUC officials, 2007.

48. Informal communication, 2003.

49. Author interview, 2007. 
in certain large U.S. cities as part of the background there.$^{50}$ More broadly, most diplomats and humanitarian workers did not relate to gross human rights violations in the Congo the way they would have in their own countries.

The understanding of violence on the Congolese population as normal and acceptable dates back to the nineteenth century. ${ }^{51}$ Through cartoons, novels, movies, museum displays, documentaries, policy discourse, and newspaper articles, the Belgian colonizers constructed the image of the Congolese "inherent savagery" to enable intervention and colonial conquest. This understanding quickly became dominant and, since then, international actors (as well as some Congolese actors) have kept on reproducing it. Even in the early twenty-first century, policymakers, journalists, and most Western and African people continued to uphold the belief that the Congolese were "by nature" brutal, barbarous, and savage, and that violence was "normal" for the Congo. When discussing the Congolese conflict, they usually emphasized the unending, puzzling, and gruesome character of the violence; the state of quasi-anarchy and chaos; the polarization of the society according to ethnic issues; and the "folkloric" aspects of the Mai Mai militias, such as reliance on supernatural powers and fighting naked..$^{52}$ They continuously referred to Conrad's Heart of Darkness and used the words "barbarian" and "barbarous." 53 They often analyzed the conflict and the peace process in Hobbesian terms. ${ }^{54}$ These recurring tropes portrayed the Congolese as irrational savages and constructed their actions as senseless and utterly foreign to civilized Western minds.

Of course, many human rights and humanitarian activists, as well as Congolese civil society actors, often contested this widespread understanding. They advocated for a better response to the continuing violence, implying that there was nothing normal about it. However, their interpretation usually remained marginalized: most international actors continued to reproduce the dominant discourse.

The main reason for this resistance to change seems to be that, in spite of their apparent influence over the transition, international actors felt powerless to end the horrific human rights abuses they witnessed. This feeling was itself the combined result of a historical frame-that of Africa as a hopeless place, where nothing can be done to improve the situation ${ }^{55}$ - and of an organizational dynamic: in a process similar to what Barnett documents, diplomats, UN staff, and NGO officials had developed a "sense of 'powerlessness' that [could lead] them to deny

50. Author interview, 2005.

51. Dunn 2003.

52. See, for example, "Heart of Darkness: The Democratic Republic of Congo," originally broadcast on ABC News Nightline in 2002; articles in Le Soir (Internet ed.), 14 February 2005, and All Africa Global Media, 9 September 2005; and Sarah J. Coleman, "Congo's Conflict: Heart of Darkness," Beliefnet, 2 June 2005, available at 〈http://www.beliefnet.com/story/167/story_16759_1.html〉. Accessed 14 January 2009.

53. Conrad 1902.

54. Author interviews, 2004-2007; The Independent, 5 May 2006; and Mampilly 2007, 193.

55. Shaw 2007. 
their capacity for action;" 56 they believed they had neither the skills nor the mandate to address the causes of continuing violence. ${ }^{57}$ In these circumstances, two distinct psychological processes combined to construct violence as normal. First, after seeing or hearing about many human rights violations, international actors became numb toward them. ${ }^{58}$ Second, they deflected violence intellectually by saying that it had been present all throughout Congolese history and therefore it was normal that it should continue. ${ }^{59}$

The understanding of violence as normal strengthened the international lack of interest in the ongoing conflict, which reinforced the financial and human resources constraints on action at the local level, which in turn heightened the international actors' feelings of powerlessness. This vicious circle was interrupted only rarely, when unusually shocking events took place.

\section{Escaping the Hobbesian World}

During the transition, five kinds of events proved so shocking that they led international actors to recategorize parts of the Congo as war environments: when supposedly peaceful areas suddenly flared up; when a crisis looked like a potential genocide; when violence was particularly gruesome or spectacular; when international peacebuilders were targeted; and when local conflict obviously jeopardized the national and regional settlements. This recategorization led to a change in strategy: international intervention ensued.

Take the example of Ituri, a district located in the northeast of the country. As detailed previously, violence continued there, just as in the other eastern provinces, mostly because of unresolved local conflict over land and mineral resources. In Ituri, however, a series of shocks led to intervention. Violence flared up rapidly in 2002-2003, although the district had been considered "peaceful" until then. Militias killed several peacekeepers, which reportedly incited the high-level UN management to launch extensive military actions. UN and European Union officials perceived the deteriorating situation as a potential genocide, which was extremely influential in compelling them to intervene. ${ }^{60}$ The European Union (EU) sent the first ever European peacekeeping operation to the Ituri capital Bunia. The UN stationed significantly more civilian and military staff members in the Ituri district

56. Barnett 2002, 10.

57. Author interviews with foreign observers, 2004, and with foreign diplomats, 2004-2007. See also the interview with Jean-Marie Guéhenno, the Under-Secretary General for Peacekeeping Operations, in Mattheiem 2005.

58. Informal communications, 2001-2007; and author participant observation, 2001-2003.

59. Such a process was particularly obvious in author interviews with a UN official, 2004; a MONUC official, 2005; and a EU official, 2004.

60. Cowan 2005. 
than in any of the other eastern provinces. ${ }^{61}$ Finally, throughout the transition, the presence of very graphic horrors (such as massacres by machetes or grisly tortures) seemed to function as a justification or a reason for intervention. MONUC press conferences usually detailed such horrors at length whenever peacekeepers stepped up their military actions in the district.

In Ituri, as in the other instances of shocking violence, the UN peacekeepers took bigger steps than diplomats and nongovernmental officials in trying to address the problem, notably by mediating ceasefires and deploying additional troops. The reason was simple: if recategorizing the Congo as a war situation did not jeopardize in any way the continued existence of embassies, foreign ministries, or nongovernmental agencies, it did threaten the UN organizational survival. In times of crises, many MONUC officials worried that the UN Security Council would withdraw the mission from a country where there was "no peace to keep." Furthermore, the resources that the UN spent on the Congo were so massive that, in many Western capitals, diplomats voiced the same admonition: the Congo was a test case for UN peacekeeping. War resumption there would be seen as a proof that, even when given a strong mandate and enormous resources, UN missions were ineffective. ${ }^{62}$

However, the categorization of the Congo was the only element of the postconflict peacebuilding frame that changed. The goal of the increased international involvement was to bring the situation back to "normal"-meaning, to a level of violence considered to be normal for a peaceful Congo. International actors also often interpreted the shocking events as a confirmation of existing beliefs. They perceived horrific violence in Ituri as further evidence of the "barbaric" character of Congolese people. They blamed regional and national leaders for the shocking violence in the Kivus (and, sometimes, in Ituri), thus further justifying their action at the macro level.

\section{A Focus on the Macro Cleavages}

Indeed, all throughout the transition, the most powerful peacebuilders- the diplomats, the donors, and the international organizations such as the MONUC and the World Bank-acted almost exclusively at the national and regional levels. They mediated and, when necessary, put pressure on the main Congolese, Rwandan, and Ugandan political and military leaders, and they closely supervised legislative and constitutional debates.

This focus on the macro level was a standard rule of action, deeply rooted in the UN and embassies' organizational cultures. When foreign embassies were created centuries ago, the goal was to develop good relationships with host govern- 
ments (and to protect one's nationals), not to get involved with subnational actors. Similarly, the United Nations was created in 1945 as an international organization, tasked with intergovernmental work. This shared definition of the diplomacies' and UN's identities has persisted until now because of a host of formal and informal mechanisms. During the international intervention in the Congo, for example, newcomers were socialized in the culture of their organization through long formal training (for diplomats) or a short induction course (for MONUC staff), and through everyday interactions with other staff members. Diplomats and UN officials moved from headquarters to the field or from one field mission to the next every couple of years. They brought to their new positions the knowledge they acquired in previous postings - and many approached the Congo exactly as if it was their previous country of deployment. ${ }^{63}$ Constant exchanges with other international actors also helped spread this shared understanding outside of the organizations. Diplomats and UN staff members met frequently for formal meetings and informal interactions. Many of MONUC's top managers were diplomats temporarily seconded to the United Nations.

This shared definition of their organizational identities shaped the UN staff members' and diplomats' understanding of their roles during the Congolese transition. ${ }^{64}$ First, it influenced the structure of the organizations as well as the expertise available: none had any specialized unit for local peacebuilding, and the staff had no training for work at the local level or for analysis of micro issues. It thus created material constraints on international involvement at the local level. Second, it enabled diplomats and UN officials posted in the Congo to claim that their organizations had always focused on the macro level, and thus it was the "natural" and "only appropriate" thing for them to do.

Third, it shaped how diplomats and international organization officials interpreted continuing local conflicts. They found (or privileged) information indicating that violence in the east was a top-down problem. The UN Secretary General reports on the Congo emphasized mostly the national and regional roots of violence. ${ }^{65}$ Security Council resolutions focused on tensions at the macro level. ${ }^{66}$ Most international interviewees, as well as official and unofficial reports, blamed national and regional actors for the continuing violence. ${ }^{67}$ These documents and interviewees contended that national politicians fueled local conflict to use it in their jostling for positions within the transition institutions. They also asserted that regional powers propped up local militias to pursue their illegal exploitation of Congolese nat-

63. Author interviews with UN officials and diplomats, 2003-2007.

64. Author interviews with Western diplomats and international organizations' staff members, 2003-2007.

65. UN Security Council 2003-2006a.

66. UN Security Council 2003-2006b.

67. It was most obvious in interviews with Jozef Smets, 2005; three other Western diplomats, 2004 and 2005; a UN official, 2005; and a foreign observer, 2004. It is similarly evident in many UN documents, such as UN Mission in the Democratic Republic of Congo (MONUC) 2007. 
ural resources. They usually presented Mai Mai militias-which, as explained above, were fragmented, micro-level armed groups that recognized no hierarchy other than their local leaders-as either controlled by President Kabila, manipulated by Kabila's advisors, and/or adequately represented by their national delegates. They often portrayed fragmented groups such as the Rwandophones, the Mai Mai, and the RCD-G, as unitary actors. To understand the local actors who were obviously not related to national or regional politicians, most international peacebuilders adopted a standardized analytical framework based on a simplified version of Collier and Hoeffler's theory: ${ }^{68}$ these local groups were motivated by greed - the control of mineral resources; therefore, it was a "law and order problem" to be addressed by national authorities.

Of course, the few NGOs that worked on local conflict resolution in the eastern provinces contested both this specific understanding of violence and the broader focus on the macro levels. ${ }^{69}$ Although they constantly asked the MONUC and the embassies to increase their involvement at the local level, they either met hostility or were limited to getting additional funding for their own programs. Contestation from within the embassies and international organizations was similarly marginalized and ultimately suppressed. A Belgian diplomat who tried to get his colleagues to focus on local conflict resolution was derided and sidestepped. In 2003, the Deputy Special Representative for the Congo, a newcomer to MONUC, tried to get the mission to develop a policy on local conflict. She was faced with derision and hostility, and her project was abandoned as soon as she left. Just as with most cases of organizational resistance to change, reform efforts failed in the Congo because they threatened entrenched organizational interests and because they fundamentally clashed with existing cultural norms. ${ }^{70}$

The UN staff and diplomats' lack of direct experience with local conflict enabled them to maintain their focus on the macro levels despite the obvious failure of this strategy. Virtually all diplomats and UN management staff stationed in the Congo were based in the capital Kinshasa, which was mostly peaceful during the transition. ${ }^{71}$ They rarely traveled outside of this city-usually at most three times a year. These trips provided participants with only basic snapshots of the local situations. Obviously, diplomats and UN staff based outside of the Congo were even less familiar with the situation on the ground. This led high-ranking UN officials and diplomats to underestimate the consequences of local violence and the need for

68. Collier and Hoeffler 2001. Such interpretations were particularly prevalent in author interviews with Jozef Smets, 2005; with a UN official, 2004; a Western diplomat, 2005; and in declarations by Western and African journalists and politicians reported in newspapers, 2003-2007.

69. This paragraph draws on author interviews with international NGOs' staff members, with Belgian diplomats, and with MONUC officials, 2003-2007.

70. See Barnett and Finnemore 2004; and Weaver 2008. For more detail on the Congo case, see Autesserre 2006a, chaps. 5 and 6.

71. This paragraph draws on author field observations; Staibano 2005; and author interviews with Jozef Smets, 2005, and other Western diplomats, UN officials, NGO representatives, and Congolese civilians, 2004-2007. 
intervention. ${ }^{72}$ An internal inquiry on the UN's failure to prevent the May 2004 generalized fighting in South Kivu faulted in part the Kinshasa staff's tendency to dismiss field reports as overly alarmist. ${ }^{73}$ Similarly, during interviews, MONUC field officers often complained that their Kinshasa and New York hierarchies did not take into account their reports warning of impending crises.

\section{From Hobbes to Locke: Electing a Leviathan}

The understanding of intervention at the macro level as the only "natural" and "legitimate" task for foreign actors also set the preconditions for the choice of a peace- and statebuilding strategy concerned almost exclusively with elections. Reconstructing a state entails many measures, including the (re)building of a bureaucracy, a justice system, effective and disciplined coercion forces, and the selection of appropriate leaders. In the Congo, the international peacebuilders focused disproportionately on one of these tasks: the selection of leaders, through elections. Apart from ad hoc action aimed at stemming crises or at ensuring that elections would proceed smoothly, the other tasks were postponed to the postelectoral period.

During the transition, all embassies and UN agencies considered elections to be "the number one priority," the "main goal of the transition."74 From 2004 onward, the Secretary General's reports on MONUC always considered the "electoral process" before talking about the "security situation." 75 During the three-year transition, embassies, UN agencies, and MONUC devoted the largest part of their financial, logistical, and human resources to the organization of the polls. ${ }^{76}$ Most interviewees never questioned this distribution of resources; it seemed "natural" or "obvious" to them because they viewed elections as the best tool for state building, and thus for peacebuilding. ${ }^{77}$

Other scholars have already studied in depth the formation of the "liberal peace" ${ }^{178}$ paradigm. ${ }^{79}$ Two trends-democratization and negotiated settlements to civil war-shaped the role of the West in conflict resolution. In the 1990s, a consensus emerged: any state that Western powers rebuild must be democratic; this would ensure both domestic and international peace. Thus, the "democratic recon-

72. Author interview with Jozef Smets 2005; and the author interview with a UN official, 2005, gave particularly detailed evidence of this process.

73. UN Mission in the Democratic Republic of Congo (MONUC) 2005.

74. Author interviews with diplomats and UN staff members, 2003-2007.

75. UN Security Council 2003-2006a.

76. Author interviews with diplomats and UN staff members, 2003-2007.

77. See, for example, the presentation of elections on MONUC's official Web site: 〈http://www. monuc.org/news.aspx?newsID $=742\rangle$. Accessed 14 January 2009. Such beliefs were also constantly voiced during interviews conducted with diplomats and UN actors (2004-2007).

78. Paris 2004.

79. See Lyons 2004; Paris 2003 and 2004; Ottaway 2002; and Youngs 2004. 
struction model" was born. ${ }^{80}$ It had elections at its core: instinctively, international peacebuilders saw free and fair elections as the primary political institution that could connect democracy assistance and peacebuilding. ${ }^{81}$ In the words of a landmark UN document, elections were supposed to promote war termination, to "replace a violent contest for political power with a non-violent one." ${ }^{82}$ Elections were also seen as key to the democratization process: they represented a return to constitutional rule and enshrined new political institutions and rules of competition. ${ }^{83}$ Thus, very different organizations-the UN, Western foreign ministries, and most Western NGOs_-developed standard operating procedures, a stock of expertise, and specialized bureaucracies to organize elections in postconflict states.

Although a focus on elections is thus a recurrent feature of recent postconflict interventions, it was neither natural nor obvious that, in the Congo, international actors should choose elections as their main state- and peacebuilding strategy. Elections can only be democratic (and thus provide legitimacy) when certain preconditions are in place, such as freedom of speech or freedom of the press. ${ }^{84}$ During the transition, the Congo lacked most of these conditions. From 2004 onward, Congolese and international actors warned that elections organized within the short timeframe of the transition would fuel ethnic tensions and generate a renewed cycle of violence. ${ }^{85}$ Indeed, the electoral campaign reinforced the power base of the extremists. The elections put in power radicals bent on cleansing the Congo of its Rwandophone population. The new administration neglected public matters and cracked down on opponents. This generated a renewed instability in many Congolese provinces. In the year following the elections, fighting and riots took place in Kinshasa, Ituri, Bas Congo, South Kivu, Katanga, and North Kivu, where it escalated into a serious threat to the general settlement.

In addition to being a poor state- and peacebuilding strategy, election organization was also a complicated task. ${ }^{86}$ Security hurdles were enormous. The Congo is an immense territory practically devoid of infrastructure, and therefore the physical organization of the polls required massive financial and logistical resources. In addition, colossal efforts were needed to train the population in democratic matters: up to the eve of the polls, most rural interviewees did not know what elections were for. ${ }^{87}$ In sum, logistical, financial, and human resources constraints hampered the organization of "free and fair" elections to a similar degree as their hampering of local peacebuilding work.

80. Ottaway 2002.

81. Youngs 2004.

82. UN Best Practice Unit 2003, 147.

83. Lyons 2004.

84. See Mansfield and Snyder 2005; and Snyder 2000.

85. See, for example, International Crisis Group 2006a.

86. Author interviews with UN staff members and foreign diplomats, 2004-2007.

87. Author interviews with villagers around Nyunzu, Shabunda, Lemera, Baraka, and Fizzi, 2004-2006. 
However, perceptions of elections and local conflict resolution differed in such ways that international actors deemed the logistical and security constraints manageable in the case of the former and not in the case of the latter. ${ }^{88}$ International actors viewed elections organization as a concrete, technical endeavor that could be pursued by bringing in specialists, who implement in all countries the best strategy possible based on their experience with ballot processes. In contrast, international actors considered peacebuilding—and especially local peacebuilding —as a multidimensional, abstract problem with no predefined solutions and indicators (both have to be tailored to each specific area). The success or failure of elections organization is easily quantifiable: election experts have developed indicators to measure the democratic, free, and fair character of the voting process. In contrast, there are often no tangible results or indicators to mark the progress or the successful completion of local conflict resolution programs. Finally, international actors viewed the election process as a short-term, time-bounded duty, with a clear beginning (the opening of the election campaign) and a clear end (the election of all necessary officials). In contrast, many interviewees characterized local peacebuilding as a "long-term" issue.

These beliefs were attractive to international actors not because they offered the only possible understanding of their role but because they overcame a number of organizational constraints and therefore enabled them to act. ${ }^{89}$ As detailed above, international peacebuilders perceived the situation of the eastern provinces as extremely messy. They lacked the expertise, bureaucratic structures, information, access, and resources to analyze local conflicts and act on them. Elections brought a simple and straightforward solution to these problems, and they supposedly worked toward the imperative of war termination, democratization, and legitimization at the same time. Organizing elections was less dangerous than mediating between warring parties. It did not require any in-depth knowledge of local issues. It could be worked on primarily at the national level. It was associated with an existing set of tools, procedures, expertise, and strategy.

Few voices contested this focus on elections. In the Kivus, civil society representatives claimed that elections should wait until peace had been established. UN officials and diplomats never listened to them. ${ }^{90}$ Beyond the Congo, many academics contested the standard use of elections as a peacebuilding strategy. ${ }^{91}$ Practitioners had little time to read this research. ${ }^{92}$

Nevertheless, international priorities could have been different. International actors could have privileged peace or justice over democracy by devoting, for exam-

88. Author interviews with diplomats, UN staff members, and NGO representatives, 2003-2007.

89. This sentence, just as the process analyzed in this paragraph, builds on the Barnett and Finnemore 2004 study of the development of analytic tools by the International Monetary Fund (IMF) staff in the early days of the organization.

90. Informal communication from civil society representative of South Kivu, October 2007.

91. See, among many others, Snyder 2000; and Paris 2004.

92. Informal communication from Western diplomat, November 2007. 
ple, the more than $\$ 500$ million spent on elections to security-sector reform, to local conflict resolution, or to a major revamping of the justice system. The Congolese people would probably have welcomed such a strategy. ${ }^{93}$ Most national elites and militia leaders had a vested interest in postponing the elections to keep their positions of authority. The rural population of the eastern provinces usually had very little understanding of what elections were about and therefore little stake in the process. It is difficult to estimate how the rest of the population would have reacted to a longer democratization process. However, according to many Congolese and international interviewees, it was only because of the massive awarenessraising programs financed by foreign donors that urban Congolese came to regard elections as the solution to the Congo's problems. Thus, a transition process carefully planned over ten years to build a lasting peace at all levels, reconstruct the administrative and economic capacity of the country, minimize visible international interference, develop the preconditions for free and fair elections, and explain the advantages of this strategy to the population would probably have been received well.

\section{Did the Postconflict Peacebuilding Frame Matter?}

Studying discursive frames is crucial to analyzing international intervention. During the Congolese transition, understandings of the transition as a "postconflict" situation, of a certain level of violence as normal for a peaceful Congo, of intervention at the national and international levels as the only "natural" and "legitimate" task for foreign actors, and of elections as a favorite peacebuilding mechanism established the parameters of acceptable action. These elements constituted a postconflict peacebuilding frame, which shaped what international actors thought of at all (this usually excluded continued local conflict), what they thought of as possible (this excluded local conflict resolution), and what they thought was the "natural" course of action in a given situation (national and international action, and in particular organizing elections) ${ }^{94}$ This frame constructed local conflict resolution as an irrelevant, inappropriate, and illegitimate task for international actors. Absent this frame, the outcome of the existing constraints and interests might have been different. International peacebuilders might have located the causes of the continuing violence at the local level. They might have contemplated intervention in local conflict; they might even have considered local peacebuilding one of their priorities. However, did this frame truly matter?

The most frequently suggested alternative explanation for the international neglect of local violence builds on neorealist theory, emphasizing that none of the major

93. Sources for this paragraph include author interviews and informal communications with elite, nonelite, urban, and rural Congolese, 2001-2007.

94. This sentence is a paraphrase of Neumann 2008, 2. 
powers had a key national interest in the Congo. This lack of major powers' interests accounted for the presence of human resources, financial, organizational, security, logistical, information, and analysis constraints on the international intervention. While there is no doubt that these constraints prevented international peacebuilders from addressing all the dimensions of the Congolese problem, no matter how inadequate, there were still significant financial and human resources, and part of these resources could have been devoted to local peacebuilding. This money would have provided much-needed funding to Congolese NGOs. They could have implemented local reconciliation projects, such as building a market, a school, or a health center between two communities in conflict to re-establish social and commercial links between them. They could also have helped reconstruct social mechanisms for the peaceful resolution of conflict, such as local justice institutions. In each observation site, MONUC could have deployed, alongside the military, a civilian staff member tasked with monitoring local tensions and providing suggestions for resolution. This civilian could have been allowed to draw on military, diplomatic, or development resources to promote local peace.

Thus, one needs to understand why international actors interpreted the lack of material and financial resources as a constraint on local peacebuilding. While I have argued that it was due to the presence of the postconflict peacebuilding frame, an alternative view would be that international actors purposely chose to ignore local conflicts. That said, drawing on neorealist, neoliberal, and organizational theory for six distinct motivations, I find such motivation lacking.

The first potential motivation is that international actors did not want to do anything about the Congo. This explanation does not hold. It is true that no major powers had any national interest in the Congo, but the size and the budget of MONUC underlined the presence of at least a limited humanitarian and geostrategic interest in the Congo on the part of the UN Security Council's member states. Furthermore, as mentioned previously, the UN had a major organizational interest in stabilizing the Congo because the mission had become a test case for UN peacekeeping.

The second potential motivation is that the permanent members of the Security Council, which mandate the peacekeeping missions, did not want to involve the UN missions in the messy areas of local conflict, except in high-priority countries such as Kovoso and Bosnia. Knowing this, the Secretary General constrained his staff from getting tied up in local strife. Again, the data does not support this explanation. The only mention of local conflict resolution in official UN and diplomatic documents is in a 2003 report of the Secretary General on MONUC. Here, the Secretary General officially endorsed the local peacebuilding initiative promoted by the then-Deputy Special Representative for the Congo. ${ }^{95}$ Otherwise, the issue was never on the agenda in high-level meetings, either to support or to proscribe it. During interviews, diplomats and UN officials based outside of the Congo presented local conflict resolution as a minor issue that had to be dealt with in the field. 
The third potential motivation is that international actors considered Congolese internal affairs, including local conflict resolution, to be the exclusive competence of the sovereign Congolese state. This explanation raises more questions than it answers. UN staff and diplomats overlooked Congolese sovereignty whenever they deemed it necessary. For example, they closely supervised the writing of the new constitution, a matter of national sovereignty above all else. Thus, one needs to understand why sovereignty was interpreted as a constraint in the case of local peacebuilding and not in the case of the constitution. That is, the postconflict peacebuilding frame constructed local conflict as much less important that national or international issues.

The fourth potential motivation is that international actors pursued only specific and limited goals in the Congo, which could be achieved with elections alone. Elections serve as symbolic endpoints for international interventions. They provide diplomats, international financial institutions, and bilateral donors with the partners they need: " 'normal,' internationally recognized governments" able and willing to implement international norms and obligations. ${ }^{96}$ In the Congo, elections also put an end to an ineffective transitional arrangement. This motivation holds for only some of the international actors, such as China. The other most active states in the Congo (France, the United States, United Kingdom, South Africa, and Belgium) needed to build a lasting peace there, and not only an internationally recognized government, in order to enhance their business opportunities and to protect their allied governments in the region. ${ }^{97}$ Similarly, because the Congo was a test case for UN peacekeeping, UN staff members knew and often emphasized that fully stabilizing the country was of the utmost importance to their organization. ${ }^{98}$

A fifth and related motivation is that the new standard operating procedures of the UN department of peacekeeping operations led to reasonable successes without involving the missions in local conflicts. ${ }^{99}$ However, one still needs to understand how "success" could be defined in a way that accommodated the continuation of violent local conflict in parts of the country.

The last potential motivation is that $\mathrm{UN}$ and foreign diplomatic teams had a strong organizational interest in downplaying the importance of local conflict. They needed to justify the minimal amount of staff and resources they devoted to the Congo to maintain their credibility, and to avoid being drawn into a situation that could become a quagmire like Somalia. They also believed that acknowledging local violations would provide a pretext for belligerent parties to walk away from, and cause a collapse of, the peace process. This is correct, but one still needs to understand why Belgian, British, French, South African, American, and above all,

96. Lyons 2004, 37. See also Woodward 2006.

97. Most Congolese hotly question this claim. They maintain that Western actors fuel violence in order to exploit the Congolese natural resources illegally. My six years of fieldwork have wielded no support for this hypothesis.

98. Author interviews with diplomats and UN staff members, 2004-2007.

99. This explanation builds on Doyle and Sambanis 2006. 
UN officials, clung to elections when faced with overwhelming proof that this strategy was failing and thus jeopardizing their core national and organizational interests. One also needs to understand why human rights and humanitarian activists so rarely contested the focus on elections as the measure for success. I have argued that all this could have happened only because of the presence of a postconflict peacebuilding frame, which similarly shaped the different organizational cultures so that staff located in very different institutional spaces shared the same understanding of elections (as a workable and legitimate peace and state building strategy), of local violence (as normal), and of the persistence of localized fighting (as unrelated to the success of the transition).

In sum, material constraints, lack of national interests, and organizational interests did play a role in preventing action on local conflict. However, these constraints and interests were not given, pre-existing, and objective. Rather, they were constituted by the postconflict peacebuilding frame, which shaped the international understanding of violence and intervention in such a way that international actors interpreted their lack of material capabilities as obstacles to local peacebuilding and their national and organizational interests as compatible with continued local conflict.

\section{Conclusion}

This article has suggested a new approach to international interventions by demonstrating that a discursive frame, composed of elements coming from the organizational, field, and world polity levels, could influence the behavior of international organizations on the ground. During the Congolese transition from war to peace and democracy, the postconflict peacebuilding frame shaped the international understanding of violence and intervention in a way that overlooked the decisive role of local agendas in sustaining violence. This frame made certain strategies (such as national and regional negotiations or election organizations) appear as legitimate and appropriate, and others (notably local conflict resolution) seem irrelevant and illegitimate. Thus, this frame proscribed international action on local violence. It channeled constraints and interests toward elections and away from local peacebuilding and ultimately doomed the international peacebuilding efforts.

The scope of this theoretical argument is not limited to the international intervention in the Congo. Recent research emphasizes the importance of local conflict in most war and postwar situations. ${ }^{100}$ However, UN staff members' and diplomats' neglect of local conflict is a recurrent pattern in third-party interventions. None of the UN peacekeeping missions around the world implements any specific program on local violence. ${ }^{101}$ Only a handful of diplomats have tried (without success) to advocate for a better approach to local issues by diplomatic groups.

100. See Kalyvas 2006; Krämer 2006; and Straus 2006.

101. Personal communications from UN officials, New York, 2005 and 2008. 
Other scholars have already pointed to the role of master narratives, such as ideas of freedom or development, in obscuring international understanding of local dynamics and ultimately leading to dysfunctional development strategies. ${ }^{102} \mathrm{Sim}-$ ilarly, this article suggests an examination of the postconflict peacebuilding frame to understand the constant neglect of local tensions and the resulting peacebuilding failures. Many of its central elements are present beyond the Congo. The UN staff and diplomats' focus on the national and international levels is a recurrent feature of international interventions ${ }^{103}$-not surprising, given that it is rooted in organizational culture. The categorization "postconflict" almost always triggers the routine adoption of tools and procedures inappropriate for conflict situations, such as an obsession with holding elections. ${ }^{104}$ The understanding of violence as a normal feature of life can also be documented for the Balkans ${ }^{105}$ and for Africa as a whole. ${ }^{106}$ It often leads international actors to perceive as normal the massive human rights violations they witness, until unusually shocking events take place.

For example, international intervention in the Sudan presents interesting parallels with the analysis developed here. The widespread interpretation of Darfur as an ethnic, Arab-versus-African war prevented international interveners from understanding the complex local dynamics of violence. ${ }^{107}$ International actors based their intervention strategy on a simplified, good-versus-evil framing of the conflict and ended up involuntarily fueling existing antagonisms. The differing response to the tensions in the western and southern parts of the country also illuminates the determining role of shocking events in jolting international actors out of their habituation to violence. The chronic war in the south caused five times more casualties than the Darfur crisis. However, the sudden eruption of horrific violence in Darfur, which was perceived as a peaceful place, attracted much more intense diplomatic and media attention than south Sudan ever did.

International actors should therefore question the widespread understandings of violence and intervention that make local peacebuilding appear irrelevant or inappropriate. This questioning would make it easier for them to listen to alternative framings of the situation, such as: the relationship between war and peace is that of a continuum, not a dichotomy; extensive violence is never a "normal" feature of life; local conflict resolution is an appropriate task for international actors; and elections are a poor peacebuilding mechanism. ${ }^{108}$

102. See Englund 2006; and Ferguson 1990.

103. See Alao, Mackinlay, and Olonisakin 1999; Badie 1995; Bigo 1996; author interview with MONUC official, 2004; and informal communication from Roland Marchal, 2004.

104. See Lyons 2004; Ottaway 2002; Paris 2004; Snyder 2000; and Stedman 1997, 50.

105. Woodward 1995.

106. Roland Marchal, personal communication, January 2004; and Shaw 2007.

107. See de Waal 2005; and Mamdani 2007.

108. See Autesserre 2008 for policy recommendations on how to implement effective local peacebuilding programs. 


\section{References}

Adam, Hussein. 2005. Peace Making and Peace Building in Somalia: A Tale of Two Political Cultures. Paper presented at the 49th Annual Meeting of the African Studies Association Conference, November, Washington, D.C.

Alao, Abiodun, John Mackinlay, and Funmi Olonisakin. 1999. Peacekeepers, Politicians and Warlords: The Liberian Peace Process. New York: United Nations University Press.

Autesserre, Séverine. 2006a. Local Violence, International Indifference? Post-Conflict 'Settlement' in the Eastern D.R. Congo (2003-2005). Ph.D. diss., New York University, New York.

- 2006b. Local Violence, National Peace? Post-War 'Settlement' in the Eastern D.R. Congo (2003-2006). African Studies Review 49 (3):1-29.

- 2007. D. R. Congo: Explaining Peace Building Failures, 2003-2006. Review of African Political Economy 34 (113):423-41.

. 2008. The Trouble with Congo-How Local Disputes Fuel Regional Violence. Foreign Affairs 87 (3):94-110.

Badie, Bertrand. 1995. La Fin des Territoires: Essai sur le Désordre International et Sur L'utilité Sociale Du Respect. Paris: Fayard.

Barnett, Michael. 2002. Eyewitness to a Genocide: The United Nations and Rwanda. Ithaca, N.Y.: Cornell University Press.

Barnett, Michael, and Martha Finnemore. 2004. Rules for the World: International Organizations in Global Politics. Ithaca, N.Y.: Cornell University Press.

Benford, Robert D., and David A. Snow. 2000. Framing Processes and Social Movements: An Overview and Assessment. Annual Review of Sociology 26:611-39.

Berger, Peter L., and Thomas Luckmann. 1967. The Social Construction of Reality: A Treatise in the Sociology of Knowledge. Garden City, N.Y.: Doubleday.

Bigo, Didier. 1996. Guerres, Conflits, Transnational et Territoire. In L'international Sans Territoire, edited by Bertrand Badie, Marie-Claude Smouts, and Wladimir Andreff, 397-418. Paris: L'Harmattan.

Braeckman, Colette. 2003. Les Nouveaux Prédateurs: Politique des Puissances en Afrique Centrale. Paris: Fayard.

Collier, Paul, and Anke Hoeffler. 2001. Greed and Grievance in Civil War. Oxford Economic Paper 56. Washington, D.C.: World Bank.

Conrad, Joseph. 1902. Youth: A Narrative and Two Other Stories [Heart of Darkness]. Edinburgh/ London: Blackwood.

Cowan, Paul. 2005. The Peacekeepers. Canada: National Film Board of Canada.

de Waal, Alex. 2005. Who Are the Darfurians? Arab and African Identities, Violence and External Engagement. African Affairs 104 (415):181-205.

DiMaggio, Paul J., and Walter W. Powell. 1983. The Iron Cage Revisited: Institutional Isomorphism and Collective Rationality in Organizational Fields. American Sociological Review 48 (2):147-60.

Doyle, Michael, and Nicholas Sambanis. 2006. Making War and Building Peace: United Nations Peace Operations. Princeton, N.J.: Princeton University Press.

Dunn, Kevin C. 2003. Imagining the Congo: The International Relations of Identity. New York: Palgrave Macmillan.

Eden, Lynn. 2004. Whole World on Fire: Organizations, Knowledge, and Nuclear Weapons Devastation. Ithaca, N.Y.: Cornell University Press.

Englund, Harri. 2006. Prisoners of Freedom: Human Rights and the African Poor. Berkeley: University of California Press.

Fearon, James D., and David D. Laitin. 2003. Ethnicity, Insurgency, and Civil War. American Political Science Review 97 (1):75-90.

Ferguson, James. 1990. The Anti-Politics Machine: 'Development,'Depoliticization, and Bureaucratic Power in Lesotho. New York: Cambridge University Press.

Finnemore, Martha. 1996. Norms, Culture, and World Politics: Insights from Sociology's Institutionalism. International Organization 50 (2):325-47. 
Fortna, Virginia Page. 2004. Where Have All the Victories Gone? War Outcomes in Historical Perspective. Paper presented at the 99th Annual Meeting of the American Political Science Association, September, Chicago.

Foucault, Michel. 1975. Surveiller et Punir: Naissance de la Prison. Paris: Gallimard.

Goffman, Erving. 1974. Frame Analysis: An Essay on the Organization of Experience. Cambridge, Mass.: Harvard University Press.

Goldhagen, Daniel Jonah. 1997. Hitler's Willing Executioners: Ordinary Germans and the Holocaust. New York: Vintage Books.

Herman, Judith Lewis. 1992. Trauma and Recovery. New York: Basic Books.

International Crisis Group. 2004. Maintaining Momentum in the Congo: The Ituri Problem. Africa Report No. 84. Brussels: International Crisis Group.

- 2006a. Congo's Elections: Making or Breaking the Peace. Africa Report No. 108. Brussels: International Crisis Group.

2006b. Katanga: The Forgotten Crisis of the Congo. Africa Report No. 103. Brussels: International Crisis Group.

International Rescue Committee. 2005. Mortality in the Democratic Republic of Congo: Results from a Nationwide Survey. New York: International Rescue Committee and Burnet Institute.

Jervis, Robert. 2006. Understanding Beliefs. Political Psychology 27 (5):641-63.

Kalyvas, Stathis N. 2006. The Logic of Violence in Civil War. New York: Cambridge University Press.

Keck, Margaret, and Kathryn Sikkink. 1998. Activists Beyond Borders: Advocacy Networks in International Politics. Ithaca, N.Y.: Cornell University Press.

Kelman, Herbert, and V. Lee Hamilton. 1989. Crimes of Obedience: Toward a Social Psychology of Authority and Responsibility. New Haven, Conn.: Yale University Press.

Klotz, Audie, and Cecelia Lynch. 2007. Strategies for Research in Constructivist International Relations. Armonk, N.Y.: M.E. Sharpe.

Krämer, Mario. 2006. The Relations Between Center and Periphery: Dynamics of Violence in KwazuluNatal, South Africa. Paper presented at the Order, Conflict, and Violence Speaker Series, Yale University, New Haven, Conn.

Licklider, Roy. 1995. Consequences of Negotiated Settlements in Civil Wars, 1945-1993. American Political Science Review 89 (3):681-87.

Lyons, Terrence. 2004. Post-Conflict Elections and the Process of Demilitarizing Politics: The Role of Electoral Administration. Democratization 11 (3):36-62.

Mamdani, Mahmood. 2001. When Victims Become Killers: Colonialism, Nativism, and the Genocide in Rwanda. Princeton, N.J.: Princeton University Press.

- 2007. The Politics of Naming: Genocide, Civil War, Insurgency. London Review of Books 29 (8). 8 March 2007. Available at 〈http://www.lrb.co.uk/v29/n05/mamd01_.html〉. Accessed 14 January 2009.

Mampilly, Zachariah. 2007. Stationary Bandits: Understanding Rebel Governance. Ph.D. diss., University of California Los Angeles.

Mansfield, Edward D., and Jack Snyder. 2005. Electing to Fight: Why Emerging Democracies Go to War. Cambridge, Mass.: MIT Press.

Mattheiem, Nathalie. 2005. Congo-un entretien exclusif avec le responsable des opérations de maintien de la paix de l'ONU Guehenno: Si on réussit, c'est toute l'Afrique qui repart. Le Soir (Internet ed.), 23 April 2005. Available at $\langle$ http://archives.lesoir.be/congo-un-entretien-exclusif-avec-leresponsable-des_t-20050423-Z0QHXG.html?queryand $=\% 22 \mathrm{Si}+$ on $+\mathrm{r} \% \mathrm{E} 9 \mathrm{ussit} \% 2 \mathrm{C}+\mathrm{c} \% 92 \mathrm{est}+$ toute $+1 \% 92$ Af $\rangle$. Accessed 14 January 2009.

Nbanda Nzambo, Honoré. 2004. Crimes Organisés en Afrique Centrale. Révélations sur les Réseaux Rwandais et Occidentaux. Paris: Duboiris.

Neumann, Iver. 2008. Discourse Analysis. In Qualitative Methods in International Relations: A Pluralist Guide, edited by Audie Klotz and Deepa Prakash, 61-77. New York: Palgrave.

Ottaway, Marina. 2002. Rebuilding State Institutions in Collapsed States. Development and Change 33 (5):1001-23. 
Paris, Roland. 2003. Peacekeeping and the Constraints of Global Culture. European Journal of International Relations 9 (3):441-73.

. 2004. At War's End: Building Peace After Civil Conflict. Cambridge: Cambridge University Press.

Porac, Joseph F., Howard Thomas, and Charles W. F. Baden-Fuller. 1989. Competitive Groups as Cognitive Communities: The Case of Scottish Knitwear Manufacturers. Journal of Management Studies 26 (4):397-416.

Power, Samantha. 2002. 'A Problem from Hell:' America and the Age of Genocide. New York: Basic Books.

Shaw, Ibrahim Seaga. 2007. Historical Frames and the Politics of Humanitarian Intervention: From Ethiopia, Somalia to Rwanda. Globalisation, Societies and Education 5 (3):351-71.

Snyder, Jack L. 2000. From Voting to Violence: Democratization and Nationalist Conflict. New York: Norton.

Staibano, Carina. 2005. Enhancing the UN Capacity. Part Two: The Democratic Republic of Congo: Enhancing UN Peacekeeping Capacity—Some Operational Aspects. Unpublished Manuscript, Department of Peace and Conflict Research, Uppsala University, Uppsala, Sweden.

Stedman, Stephen John. 1997. Spoilers Problems in Peace Processes. International Security 22 (2):5-53.

Stedman, Stephen John, Donald Rothchild, and Elizabeth M. Cousens. 2002. Ending Civil Wars: The Implementation of Peace Agreements. Boulder, Colo.: Lynne Rienner.

Straus, Scott. 2006. The Order of Genocide: Race, Power, and War in Rwanda. Ithaca, N.Y.: Cornell University Press.

Touval, Saadia, and William Zartman. 1985. International Mediation in Theory and Practice. Boulder, Colo.: Westview Press.

United Nations (UN) Best Practice Unit. 2003. Handbook on United Nations Multidimensional Peacekeeping Operations. New York: United Nations.

UN Mission in the Democratic Republic of Congo (MONUC). 2005. MONUC and the Bukavu Crisis. New York: United Nations, Department of Peacekeeping Operations, Best Practices Unit.

— 2007. DRC Profile. 'Why are the Problems Still Continuing Today?' Previously available at 〈http://www.monuc.org/news.aspx?newsID=885〉. Accessed October 2007.

UN Security Council. 2003. Second Special Report of the Secretary General on the United Organization Mission in the Democratic Republic of Congo. S/2003/566. 27 May 2003. New York: United Nations.

2003-2006a. Reports of the Secretary General on the United Organization Mission in the Democratic Republic of Congo. Reports 14 through 23. New York: United Nations. Available at 〈http://www.un.org/Depts/dpko/missions/monuc/monucDrp.htm〉. Accessed 14 January 2009.

- 2003-2006b. Resolutions 1711, 1671, 1653, 1649, 1635, 1621, 1616, 1596, 1592, 1565, 1555, 1552, 1533, 1522, 1501, 1499, 1493, and 1489. New York: United Nations.

U.S. Department of State. 2007. Background Note: Democratic Republic of the Congo. Updated October 2008. Available at 〈www.state.gov/r/pa/ei/bgn/2823.htm〉. Accessed 14 January 2009.

Van Acker, Frank, and Koen Vlassenroot. 2000. Youth and Conflict in Kivu: 'Komona Clair.' Journal of Humanitarian Assistance. Previously available at $\langle\mathrm{http} / / / \mathrm{jha}$.ac/〉. First accessed April 2002.

Vlassenroot, Koen, and Timothy Raeymaekers. 2004. Conflict and Social Transformation in Eastern D.R. Congo. Gent, Belgium: Academia Press Scientific.

Vlassenroot, Koen, and Hans Romkema. 2002. The Emergence of a New Order? Resources and War in Eastern Congo. Journal of Humanitarian Assistance. Available at $\langle\mathrm{http}: / / \mathrm{jha}$.ac/articles/a111.htm $\rangle$. Accessed 14 January 2009.

Walter, Barbara F. 2002. Committing to Peace: The Successful Settlement of Civil Wars. Princeton, N.J.: Princeton University Press.

Weaver, Catherine. 2008. Hypocrisy Trap: The World Bank and the Poverty of Reform. Princeton, N.J.: Princeton University Press.

Weick, Karl E. 1995. Sensemaking in Organizations. Thousand Oaks, Calif.: Sage Publications.

Weinstein, Jeremy. 2005. Autonomous Recovery and International Intervention in Comparative Perspective. Unpublished manuscript, Center for Global Development, Washington, D.C. 
Willame, Jean-Claude. 1997. Banyarwanda et Banyamulenge: Violences Ethniques et Gestion de L'identitaire au Kivu. Bruxelles/Paris: Institut Africain-CEDAF/L'Harmattan.

Wilmer, Franke. 2002. The Social Construction of Man, the State, and War: Identity, Conflict, and Violence in Former Yugoslavia. New York: Routledge.

Wood, Elisabeth Jean. 2000. Forging Democracy from Below: Insurgent Transitions in South Africa and El Salvador. New York: Cambridge University Press.

Woodward, Susan L. 1995. Balkan Tragedy: Chaos and Dissolution After the Cold War. Washington, D.C.: Brookings Institution.

2006. Why State-Building? Toward a Conceptual Framework. Program on States and Security, City University of New York.

Youngs, Richard. 2004. Democratic Institution-Building and Conflict Resolution: Emerging EU Approaches. International Peacekeeping 11 (3):526-43.

Zartman, I. William. 1989. Ripe for Resolution: Conflict and Intervention in Africa. New York: Oxford University Press. 